\title{
Institutionalization of Islamic Law In Indonesia
}

\author{
Khairuddin ${ }^{1}$, Idzam Fautanu ${ }^{2}$
}

\begin{abstract}
Institutionalization of Islamic Law In Indonesia. This article discusses the institutionalization of Islamic law into national law in Indonesia. The aim is to analyze the possibility of incorporating Islamic Law into the national legal system. This desire is logical, considering that Muslims in Indonesia occupies the majority position (85\%) and the community requires appropriate regulations sourced from the teachings of their religion. Based on the results of the 1979/80 BPHN legal review seminar, there are at least 3 (three) main things that could be done, namely; (1) making Islamic law one of the ingredients in the preparation of national law, (2) reviewing and updating national legal products originating from colonial law that is not following the elements of Islamic law. (3) coordinating new regulations which contain Islamic legal norms. This study finds the fact that not all provisions of Islamic law can be incorporated into national law. Only provisions of a civil nature and which are truly correlated with public order (public interest) can be adopted. Apart from that, the law is not only a legal product but also a political product. In other words, the configuration of legal politics in Indonesia shows a very close relationship with the political realm. Therefore, it is necessary to have a strong synergy between Muslim intellectuals and political actors.
\end{abstract}

Keywords: Islamic law, legal politics in Indonesia, political configuration.

Abstrak: Pelembagaan Hukum Islam di Indonesia. Artikel ini membahas tentang pelembagaan hukum Islam ke dalam hukum nasional di Indonesia. Tujuannya adalah untuk menganalisis kemungkinan untuk memasukkan Hukum Islam ke dalam sistem hukum nasional. Keinginan ini didukung oleh fakta bahwa umat Islam di Indonesia menduduki posisi mayoritas (85\%) dan masyarakat muslim memerlukan adanya peraturan yang sesuai dan bersumber dari ajaran agama mereka. Berdasarkan hasil seminar pengkajian hukum BPHN tahun 1979/80 sekurangkurangnya ada 3 (tiga) pokok hal yang dapat dilakukan, yakni; (1) menjadikan hukum Islam sebagai salah satu bahan dalam penyusunan hukum nasional, (2) meninjau ulang dan memperbarui produk hukum nasional yang bersumber dari hukum kolonial yang tidak sesuai dengan unsur-unsur hukum Islam, (3) mengkoordinasikan peraturan-peraturan baru yang di dalamnya mengandung norma-norma hukum Islam. Penelitian ini menemukan fakta bahwa tidak seluruh ketentuan-ketentuan hukum Islam dapat dimasukkan ke dalam hukum nasional. Hanya ketentuan-ketentuan yang bersifat keperdataan dan sungguh-sungguh berkorelasi dengan ketertiban umum (kepentingan publik) yang dapat diadopsi. Selain dari itu, Undangundang bukan hanya produk hukum semata, melainkan juga produk politik. Dengan kata lain, konfigurasi politik hukum di Indonesai memperlihatkan adanya keterkaitan yang sangat erat

${ }^{1}$ Fakultas Syariah Universitas Islam Negeri Raden Intan Lampung, Indonesia

${ }^{2}$ Universitas Islam Negeri Sunan Gunung Jati Bandung, Indonesia

E-mail: ${ }^{1}$ khairuddinmh@radenintan.ac.id, ${ }^{2}$ idzamfautanu@uinsgd.co.id 
dengan dunia politik. Karena itu diperlukan adanya sinergi yang kuat antara kaum intelektual muslim dengan para pelaku politik.

Kata Kunci: hukum Islam, politik hukum di Indonesia, konfigurasi politik.

\section{Introduction}

Indonesian state does not adhere to a theocratic understanding which bases state administration on a particular religion. ${ }^{1}$ The state of Indonesia also does not adhere to secularism, namely the notion which assumes that there is a disparity between religion and the state. ${ }^{2}$ The relationship between religion and the state that is following the tendency of the Indonesian people is not in a dichotomous position, in the sense of separating religion from state life. ${ }^{3}$ This kind of understanding is called the 'symbiotic paradigm', ${ }^{4}$ which places religion and state life in a parallel position where Islamic law occupies a strategic position as a source of legitimacy. ${ }^{5}$

${ }^{1}$ According to theocracy theory, state and religion are two things that cannot be separated and must be carried out based on God's word. In other words, the order of life of the community, nation, and state should be carried out according to God's commands as contained in the holy book. This understanding is also called the integralists paradigm, namely the notion which assumes that religion and the state are inseparable units. Both are two integrated institutions, which means a religion functions both as a political institution as well as a religious institution.

2 Adherents of secularism confirm that religion and the state are two different entities, each has its respective areas of cultivation. Therefore, their existence must be separated and cannot interfere with each other. Based on this dichotomous understanding, positive law is the law that comes from the human agreement through social contracts and has nothing to do with religious law.

3 According to the concept of the symbiotic paradigm, which is applied in Indonesia, religion and the state are different entities, but both are understood to need each other reciprocally. Religion needs the state as an instrument in preserving and developing religion, the state, on the other hand, also needs religion, because religion also helps in fostering morals, ethics, and spirituality in the society.

${ }^{4}$ H Hasyim Muzadi, "Islam Rahmatan Lil 'Alamin, Towards Justice and World Civilization, (Nahdlatul Ulama Perspective)" (Speech of Honoris Causa Doctor Inauguration, delivered before the Open Senate Meeting of IAIN Sunan Ampel Surabaya, IAIN Sunan Ampel Surabaya, December 2006), 3.

${ }^{5}$ Indonesia does not adhere to a theocracy that is based on a certain religious ideology and is not affiliated with a secular state that does not care about religion. The concept of the relationship between religion and the state applied in this country is that religion and the state are different entities, but both are understood to need each other reciprocally. Religion requires the state as an instrument in preserving and developing religion, on the other hand, the state 
In the Indonesian context, the position of religion in the state is very strong as reflected in the text of the first precepts of Pancasila, namely 'Belief in One God' and strengthened again in Article 29 Paragraph (1) of the 1945 Constitution which states that "The state is based on the One Godhead". This precept is a fundamental positive law, intended for the Indonesian people to always view and make it a binding law at all times in personal life, in society, as a nation, and as a state. ${ }^{6}$ Given that Islam is a religion followed by the majority of the population, Islamic law must be an absolute element in the formation of national law. ${ }^{7}$

Based on the results of the 1979/80 BPHN legal review seminar, there were at least three main things that could be done to incorporate Islamic law into the national legal system, namely; (1) making Islamic law one of the ingredients in the preparation of national law, (2) reviewing and updating national legal products originating from colonial law that is not following the elements of Islamic law. (3) coordinating new regulations which contain Islamic legal norms. ${ }^{8}$

This paper attempts to answer two problems of the institutionalization of Islamic law in Indonesia; first, the position of Islam within the framework of the Unitary State of the Republic of Indonesia (NKRI), and second, the political configuration of the institutionalization of Islamic law in the Indonesian context.

This research is library research whose material is based on data and information obtained from many library sources, such as books, laws and regulations, literature, journals, magazines, documents, encyclopedias, dictionaries, and others. ' The collected data is then analyzed using scientific logic to answer the core of the study through rational and argumentative thinking.

also needs religion, because religion can help the state in the moral, ethical, and spiritual development of the community.

${ }^{6}$ Siti Mahmudah, "The Contextualization of Sharia and Its Contribution to the Development of the Indonesian National Law," Al-'Adalah 16, no. 1 (t.t.): 2019.

${ }^{7}$ Mardani, Hukum Islam Dalam Hukum Positif Indonesia (Jakarta: Raja Wali Pers, 2017), 5.

${ }^{8}$ Mura P. Hutagalung, Hukum Islam Dalam Era Pembangunan (Jakarta: In Hill Co, 1985), 6.

${ }^{9}$ Kartini Kartono, Pengantar Metodologi Riset Sosial (Bandung: Mandar Maju, 1990), 33. 


\section{Islamic Law in Legal Terminology}

A. Qodri Azyzy said that the position of Islamic law in the terminology of legal science has a specific and strategic relationship. ${ }^{10}$ This is based on several arguments. First, Islamic law is a legal system in the Muslim world whose main source is God's revelation. The law is considered to have accountability or consequences in the hereafter. Islamic law material can be in the form of law that comes directly from revelation or law that is the result of the ijtihâd (legal finding) of the mujtahidin (legal finders). Even though in practice, the material of Islamic law is mostly the result of ijtihâd, so it is loaded with individual and environmental influences, but because the thinking is based on revelation, the results of ijtihâd are considered as law based on religious values.

The Islamic legal system is one of the three legal systems in the world, besides Roman Law and Common Law. The legal system used by the Dutch colonial government was the Roman Law system, while the legal system used in England and the United States is the Common Law system. ${ }^{11}$ Each of the three legal systems has its specifications, and at the same time, can complement each other as well as compete in an evolving legal system.

Second, Islamic law can be a source of positive law (laws, judges' decisions, and jurisprudence), especially written law.

Third, Islamic laws can also be a source of unwritten law that can be used as a guide for judges in deciding cases. In this context, a judge deciding a case can get inspiration from Islamic law or even fully explore it from Islamic law. This is in line with the judicial system in Indonesia which recognizes the position of judges as sources of law as well as provides opportunities for judges to explore laws from unwritten sources.

Fourth, Islamic law has the same characteristics as general law. It

${ }^{10}$ A. Qodri Azizy, Eklektisme Hukum Nasional, Kompetisi Antara Hukum Islam dan Hukum Umum (Yogyakarta: Gama Media, 2004), 122-26.

${ }^{11}$ Jimly Asshiddiqie, Pengantar IlmuHukum Tata Negara (Jakarta: Rajawali Pers, 2010). 
has a method in its formation and provides sanctions for people who violate it. These two laws, although their status is different, have the same goal to create order in society. In this context, fiqh can be positioned as a science of law, and the thought of scholars (fuqahâ/mujtahidinn) is positioned as a doctrine or the opinion of legal experts. Both have an equal position with the opinion of legal experts in the general legal system. Likewise, references containing Islamic law can be positioned as rechtboek (books of law) which function as guidelines for judges, as well as as a source of law.

Fifth, Islamic law, as religious law and moral law, as practiced by its adherents as a form of performing religious teachings that have consequences for the hereafter. In short. Islamic law has become a living law in society so that it can be used as material to form positive law.

\section{Theories About the Application of Islamic Law in Indonesia}

There are several popular theories used to examine the institutionalization of Islamic law in Indonesia.

\section{a. The theory applied in the Pre-Independence era}

Among the well-known theories in the pre-independence era that can be used to examine the institutionalization of Islamic law in positive law are:

(1) Receptio in complexu theory. This theory was pioneered by Lodowijk Willem Christian van den Berg (1845-1927). ${ }^{12}$ According to this theory, Indonesian Muslims have received Islamic law as a whole and as a unit. In other words. ${ }^{13}$ Islamic law practiced by Indonesian Muslims is not only a part or parts but the whole. Applying this theory, the Dutch government, in its legal policy, acknowledged the application of Islamic law in Indonesia. The form of this recognition

${ }^{12}$ A. Qodri Azizy, Eklektisme Hukum Nasional, Kompetisi Antara Hukum Islam dan Hukum Umum, 164.

${ }^{13}$ Khotibul Umam, "Legalisasi Fikih Ekonomi Perbankan: Sinkronisasi Peran Dewan Syariah Nasional dan Komite Perbankan Syariah,” Mimbar Hukum 24, no. 2 (Juni 2012): 360. 
was born in Staatsblad 1882 No. 152 concerning the establishment of Religious Courts in Java and Madura.

(2) Receptie theory. This theory is the opposite of the theory of receptio in complexu. The pioneer of this theory was Cornelis Snouck Hurgronje. Based on his research in Aceh and Gayo Land, Snouck Hurgronje concludes that the law that applies among the Acehnese and Gayo people is customary law, not Islamic law, although it must be admitted that in the customary law it is largely rooted in Islamic law. ${ }^{14}$ This theory had a considerable influence on the Colonial Government, which led to the official attitude of the Dutch government to review Staatsblad 1882 No. 152 and then issued Staatsblad 1937 No. 116, which revoked the authority of the Religious Courts to hear family law cases for Muslims and delegated them to the Landraat (District Courts) authority. ${ }^{15}$

Second, the theory applied in the Post-Independence era

\section{b. The theory applied in the Post-Independence era.}

After independence, the process of institutionalizing Islamic law into national law was bridged by at least four theories, namely:

(1) Receptio exit theory. This theory was initiated by Hazairin. This theory states that the old law is seen as still valid as long as its soul does not conflict with the 1945 Constitution. Based on this theory, all Dutch government laws and regulations based on the receptie theory are considered no longer valid because they are contrary to the 1945 Constitution and must be revoked.

(2) The theory of receptio a contrario was raised by Sayuti Talib. ${ }^{16}$ This theory holds that the principle for Muslims applies Islamic law because this is following the ideals of law and the beliefs and morals

\footnotetext{
${ }^{14}$ Isa Ansori, "Kedudukan Fatwa di Beberapa Negara Muslim," Analisis 3, no. 1 (Juni 2017).

${ }^{15}$ Muhammad Daud Ali, Hukum Islam : Pengantar Ilmu Hukum dan Tata Hukum Islam di Indonesia (Jakarta: PT. Raja Grafindo Persada, 1996), 219.

${ }^{16}$ Darmansyah, "Mimbar Hukum Islam," Yayasan Al-Hikmah Bekerjasama dengan Direktorat Pembinaan Peradilan Agama Islam dan Penyelenggaraan Haji Departemen Agama Republik Indonesia, XV 2004, 35.
} 
of Muslims themselves. Customary law as well as other laws in the country applies to Muslims as long as they do not conflict with the norms of Islamic teachings and Islamic law. The philosophy of this theory is that, based on Pancasila and the 1945 Constitution, religious people should perform and obey the laws of their religion following the first precepts of Pancasila and Article 29 of the 1945 Constitution.

(3) The theory of existence, which was developed by Ichtianto. This theory explains that Islamic law exists in the legal system in Indonesia. Islamic law is an integral part of Indonesian national law because of its independence, strength, and authority. Islamic legal norms function as material for national law as well as the main filter in the development of law in Indonesia. ${ }^{17}$

(4) The theory of renewal. This theory was pioneered by Bustanul Arifin, Ismail Sunni, and Tahir Azhari. According to them, there is no customary law, only tradition. Customary law which has been termed by many people is just engineering of the Dutch East Indies Government, which through its legal experts, determined that in Indonesia there are customary law areas that are divided into 19 jurisdictions. Although in Indonesia there are, indeed, various customs that differ from one region to another, this does not mean that every region has customary law.

Based on the description above, it can be drawn that the implementation of Islamic law in Indonesia, both the era before and after independence, has proportionally gained a place although it is still not fully. This can be proven by the existence of legal products that regulate many matters including marriage, inheritance, wills, endowments, grants, alms, muamalah (Islamic economy), and several regulations on ethics and morality in social and state life.

The historical and sociological facts above clearly show that Islamic law, as the law of religion, is followed and believed by people. Its

17 Ikhtianto, Pengembangan Teori Berlakunya Hukum Islam di Indonesia, dalam Tjun Suryaman (ed), Hukum Islam di Indonesia, 2 ed. (Bandung: Remaja Rosdakarya, 1994), 137. 
existence has a very important position in the legal development process in Indonesia. By paying attention to these juridical facts, the future strategy for developing law in Indonesia must consider religious values, including legal values and traditions (customs) that are alive and become community beliefs. ${ }^{18}$ Materials derived from the above legal sources can be accommodated into law-forming materials in Indonesia through the identification of the commonalities of principles and methods contained in these various legal sources. For this reason, a very important issue that needs to be done now is to conduct intensive research and study on Islamic norms and values following other legal principles and sources. By finding the similarity of values and principles, automatically Islamic law can be easily accepted by all parties and can be formulated into a ius constitutum to meet the legal needs of the Indonesian people under the auspices of Pancasila and the 1945 Constitution.

\section{Islamic Law as a Source of National Law}

Legal sources can be divided into two types, namely formal legal sources and material legal sources. Formal sources of law are sources of law that have a certain form and are binding as a law because they have been determined (enacted) by the authorized institution. Meanwhile, material legal sources are legal materials that do not yet have a certain form and are not yet binding as a legal product. ${ }^{19}$ One form of the formal legal source is the law which consists of a set of rules that are hierarchically structured and have a certain form. Apart from becoming law, sources of formal law can also be in the form of jurisprudence, conventions, and legal doctrines. Jurisprudence is a court decision that has permanent legal force and has been accepted as a guideline by judges in dealing with the same case. A convention is a practice of state administration and government that comes from tradition (unwritten) but is accepted

${ }^{18}$ Ma’ruf Amin, "Solusi Hukum Islam Makharij Fiqhiyah Sebagai Pendorong Arus Baru Ekonomi Syariah di Indonesia” (Malang, Mei 2017).

19 Khairuddin dan M. Iwan Sastriawan, Hukum Tata Negara, Pasca Amandemen UUD Negara Republik Indonesia (Jakarta: RajaGrafindo, 2018), 14. 
as a norm. While the doctrine is the opinion of experts who influence society due to their expertise.

Bagir Manan, when discussing the sources of law from the aspect of constitutional conventions, stated that the investigation of the sources of law will provide clues about how and where the law is located. In the context of Islam, formal sources of law mean "the provisions of Allah revealed to humans through His Messenger, which in this case is the Qur'an and the Sunnah of the Prophet. Meanwhile, the practice of religious norms in everyday life can be classified as a source of material law for the community concerned and is part of the unwritten rules (law). In every country, the unwritten rules grow and develop side by side with written legal rules. Except in the field of criminal law (material), all fields of law accept the presence of unwritten rules and are recognized as one of the important sources in constitutional law. ${ }^{20}$

The question now is whether religious law is a formal source of law. or material sources. N.E. Van Duyvendijk, as quoted by Bagir Manan, places religious law as part of the source of material law in the traditional group (religious and moral opinions, traditions in the field of law). On the other hand, Utrecht includes religion (religious law) as a source of formal law, with the consideration that in areas (Indonesia) where the way of life of the population is strongly bound by religion, the position of religious law as a source of law is very important. ${ }^{21}$

The differences of opinion above do not reduce the meaning of the position of religious law as a source of law. Both opinions clearly illustrate the recognition of legal science towards religion, both as a formal legal source (as an authoritative legal document) and as a material legal source (material determinants form law).

Two kinds of Islamic law apply in Indonesia, namely normative and formal-juridical. Normative Islamic law is part of the Islamic law that has social sanctions if its norms are violated. The strength of the social sanctions depends on the strength and weakness of the Muslim

\footnotetext{
${ }^{20}$ Bagir Manan, Konvensi Ketatanegaraan (Bandung: Armico, 1987), 85.

21 Bagir Manan, Konvensi Ketatanegaraan
} 
community's awareness of these norms. Prayer, zakat, fasting, and hajj, including parts of the Islamic law that regulates human relations with God (worship) are examples of normative Islamic law. Whether or not Islamic law applies normatively in Indonesian Islamic society depends on the level of faith.

Formal-juridical type of Islamic Law is represented by Islamic law which regulates human relations with other humans and material matters. The transition of the Islamic law that applies formal-juridical to positive law is carried out through a legislative process and involves all government components (executive, legislative and judicial). The legal products resulting from this positivity are marriage law, inheritance law, and compiled waqf law, or other Islamic legal provisions that have been adopted into the national legal system.

Making fiqh books or fatwas stipulated by the mufti as a source of material law has long been practiced in the history of government in Indonesia. From the Dutch colonial era until now, fatwas from muftis, as well as fiqh resulted from ijtihâd of mujtahids, have contributed greatly to the formation of shari'ah-based legal norms as well as being a guide in directing the life of the Muslim community in the country. Such conditions have continued for centuries since Islam entered the archipelago until now.

Fiqh and fatwas, although diverse and very likely to contradict one another, are already part of the needs of the Indonesian Muslim community, especially to implement religious orders. Compared to constitutional conventions which are unwritten legal rules, as referred to in the explanation of the 1945 Constitution before it was amended, ${ }^{22}$ Fiqh and fatwas have occupied a position similar to conventions in the practice of sharia. Guidelines for obeying fiqh and fatwas are not clearly stated in the Qur'an and as-Sunnah, as compared to the status of conventions in the Constitution, but the only affirmation of the

${ }^{22}$ The explanation of the 1945 Constitution (before amended): "The Constitution of a country is only part of the basic law of the country. The Constitution is a written basic law, while in addition to the Basic Law the unwritten basic law also applies, namely the basic rules that arise and are maintained in the practice of state administration even though they are not written. 
Qur'an about the obligation to obey Allah and His Messenger and ulil amri from among the people.

The analogical thought pattern (qiyâs) above will ultimately lead to the same conclusion that although the convention does not have legal coercion power, legal sanctions, legal remedies, or institutions that can be directly used to force law compliance, in reality, the convention is obeyed and effective in society. Likewise, figh, as a normative description of shariah, and fatwas, as legal opinions or decisions from the mufti on certain issues, both do not have the power to be forced legally (law enforcement), but only in the form of moral sanctions and religious emotions through the emergence feelings of guilt or the fear of dealing with the power of public opinion. These are the factors why Muslims obey fiqh and fatwas.

\section{Political Configuration of Islamic Law Institutions in Indonesia}

Islamic law can be the source of national law along with Western law and customary law. The source of law here must be interpreted as a source of material law in the sense of being content material for formal legal sources. Islamic law in the legal dimension has gone through a long history and has a different style from time to time. In some countries, Islamic law legislation (taqnîn) has been attempted by incorporating Islamic law into legislation. As the era of the revival of Islamic law, efforts to implement Islamic law must be carried out through the tools of state power.

In Indonesia, the process of establishing Islamic law into national law is marked by the inclusion of several aspects of Islamic law into the law, either directly mentioning it with the term Islamic law or not. The main objective is to find a conformity between Islamic law and national law. This conformity will avoid conflict within all Muslims wanting to obey their religion while loving their homeland. By establishing Islamic law into national law, differences in fiqh will be avoided.

The process of establishing Islamic law as a written rule in Indonesia has occurred in the two decades since the proclamation was announced and has taken place in stages. The first stage is that the judges of the 
Religious Courts/Shari'ah Courts are recommended to use certain fiqh books as guidelines in deciding cases. ${ }^{23} \mathrm{Next}$, the books of fiqh are used as reference standards for judges. As there are many reference books to use, the idea of carrying out a Legal Compilation on the norms of Islamic law contained in the figh books emerged. Finally, the compilation is stipulated as part of the formal legal sources in Indonesia through Presidential Instruction No. 1 of $1991 .^{24}$

Most of the provisions of the Islamic law that have been positivized into national law relates to private law, ${ }^{25}$ For examples, Law no. 1 of 1974 concerning Marriage; Presidential Instruction No. 1 of 1991 concerning the Compilation of Islamic Law (KHI); Law no. 7 of 1987 concerning the Religious Courts which was later changed to Law no. 3 of 2006, then revised again into Law no. 50 of 2009; Law no. 17 of 1999 concerning the Implementation of Hajj which was later changed to Law no. 13 of 2008; Law no. 38 of 1999 concerning Zakat Management, later amended to become Law no. 23 of 2011; Law no. 18 of 2001 concerning Special Autonomy for the Province of the Special Region of Aceh Darussalam, Law no. 41 of 2004 concerning Waqf; Law no. 21 of 2008 concerning Sharia Banking; Law no. 19 of 2008 concerning State Sharia Securities (SBSN); and Law no. 33 of 2014 concerning Halal Product Guarantee (JPH).

The series of events above show that the institutionalization of Islamic law into national law cannot be done immediately but requires

${ }^{23}$ The recommendation to use the guidelines for certain books is based on the Circular Letter of the Bureau of Religious Courts No. 8/1/735 dated 18 February 1959 as the executor of PP No. 45/1957, in letter B it is emphasized that to obtain legal unity in examining and deciding cases, religious court judges are recommended to use 13 books of fiqh as follows: (1) al-Bajûri, (2) Fathul Muîn, (3) Syarqawi' ala at-Tahrîr, (4) Qalyubi/Mahallî, (5) Fath al-Wahhab with his search, (6) Tuhfah, (7) Targhîb al-Musytaq, Qawânin al-Syar'iyyah li Sayid Shadaqah Dahlan, (10) Syamsûri fi al-Farâidh, (11) Bughyah al-Musytarsyidin, (12) al-Fiqh 'alâ Madzahib al-Arba’ah; dan (13) Mughni al-Muhtâj.

${ }^{24}$ Compilation of Islamic Law in Indonesia (KHI) in Presidential Instruction No. 1 of 1991, contains three books, namely on marriage, inheritance, and waqf.

Islamic law in Indonesia has made a very large contribution in the formation of national law since the pre-independence era, the post-independence era, especially in the reform era, at least from the aspect of substance.

${ }^{25}$ Islamic law in Indonesia has made a very large contribution to the formation of national law, especially from the aspect of substance from the pre-independence era to the present. 
a time-consuming process. Apart from that, it also requires support from the holders of power/government, or in other words, it is closely related to politics. Indeed, laws are not only legal products but also political products. It is a legal language of a political decision to achieve a common goal.

Bringing Islamic law to the legislative path needs to pay attention to three things: substance, form, and process. In terms of substance, as stated earlier, all of the doctrines contained in fiqh, ijtihâd, fatwas of scholars, as well as judges' decisions in the form of jurisprudence that have been accommodated in statutory regulations, are the main references that cannot be ignored. In terms of form, the scope of its validity must be adjusted to the hierarchical level of the legislation in the Republic of Indonesia. Meanwhile, in terms of the process, efforts to legislate Islamic law into national law at least can be done through two approaches: an academic approach and a political approach. Through these approaches, Islamic law legislation will not only result in the acceptance of all elements of the nation for the passage of legal products but also will gain strong legal legitimacy among the Muslim community itself.

It should be emphasized here that the positivization of Islamic law into national law does not necessarily involve all fields of law. For the time being, it is sufficient to focus on fields that are civil in nature (private law) and which are truly correlated with public order (public interest). This is because the heterogeneity aspect of the nation consisting of various ethnic groups and religions cannot be denied at all. Moreover, the application and institutionalization of Islamic law at all times is always followed by pro and contra attitudes from the internal circles of the Muslims themselves. This happens because there is no unity in understanding fiqh. Whereas the positivization of Islamic law into national law is actually intended to create legal uniformity for the Indonesian Muslim community.

The strategy of the Islamic legal legislation process, as described above, is different from the receptie concept in the past colonial era. Such because the receptie route does not recognize strategic efforts and does not use democratic means. Its realization is carried out through 
indoctrination, instead. It is in this context that Islam as a religion embraced by the majority of the Indonesian population has prospects in the development of national law.

\section{Conclusion}

Based on the description above, several conclusions can be drawn as follows. The legal system in Indonesia, although not based on a particular religion, provides space for the religions adopted by the people to become sources of law or provide legal material for national legal products.

The urge to incorporate Islamic legal norms into the national legal system is supported by the fact that Muslims must carry out their religious teachings as a whole, including in the legal aspect. The call to carry out this religious order will never perish and will always be present in every phase of people's lives. As long as all elements of the Umah can be united and go hand in hand with the needs of the community, Islamic law that is inherent and living in society (living law) can be institutionalized or positive into the national legal system.

The political configuration of the institutionalization of Islamic law into national law shows that the formation of law is closely related to politics because legal products are also political products. In other words, The configuration of legal politics in Indonesia shows that there is a very close relationship between the legal and political world. Therefore, it is necessary to have a strong synergy between Muslim intellectuals and political actors.

\section{Bibliography}

Ali, Muhammad Daud. Hukum Islam : Pengantar Ilmu Hukum dan Tata Hukum Islam di Indonesia. Jakarta: PT. Raja Grafindo Persada, 1996. Amin, Ma’ruf. "Solusi Hukum Islam (Makhârij Fiqhiyah) Sebagai Pendorong Arus Baru Ekonomi Syariah di Indonesia." Malang, Mei 2017.

Ansori, Isa . "Kedudukan Fatwa di BeberapaNegaraMuslim." Analisis 3, no. 1 (Juni 2017). 
Asshiddiqie, Jimly. Pengantar IlmuHukum Tata Negara. Jakarta: Rajawali Pers, 2010.

Azizy, A. Qodri. Eklektisme Hukum Nasional, Kompetisi Antara Hukum Islam dan Hukum Umum. Yogyakarta: Gama Media, 2004.

Darmansyah. "Mimbar Hukum Islam." Yayasan Al-Hikmah Bekerjasama dengan Direktorat Pembinaan Peradilan Agama Islam dan Penyelenggaraan Haji Departemen Agama Republik Indonesia, XV 2004. Ikhtianto. Pengembangan Teori Berlakunya Hukum Islam di Indonesia, dalam Tjun Suryaman (ed), Hukum Islam di Indonesia. 2 ed. Bandung: Remaja Rosdakarya, 1994.

Kartono, Kartini. Pengantar Metodologi Riset Sosial. Bandung: Mandar Maju, 1990.

Khairuddin dan M. Iwan Sastriawan. Hukum Tata Negara, Pasca Amandemen UUD Negara Republik Indonesia. Jakarta: RajaGrafindo, 2018.

Mahmudah, Siti. "The Contextualization of Sharia and Its Contribution to The Development Of The Indonesian National Law." Al-'Adalah 16, no. 1 (t.t.): 2019.

Mardani. Hukum Islam Dalam Hukum Positif Indonesia. Jakarta: Raja Wali Pers, 2017.

Manan, Bagir. Konvensi Ketatanegaraan. Bandung: Armico, 1987.

Muzadi, Hasyim. "Islam Rahmatan Lil 'Alamin, Menuju Keadilan dan Peradaban Dunia, (Perspektif Nahdlatul Ulama).” Dipresentasikan pada Pidato Pengukuhan Doktor Honoris Causa, disampaikan dihadapan Rapat Senat Terbuka IAIN Sunan Ampel Surabaya, IAIN Sunan Ampel Surabaya, Desember 2006.

Mura P. Hutagalung. Hukum Islam Dalam Era Pembangunan. Jakarta: In Hill Co, 1985.

Suhendi, Hendi Hendi, Mohammad Rusfi, N Hidayah, Deni Kamaludin Yusup, Burhanudin Hamnach, Cate Sumner, Khairuddin Khairudin Tahmid, dkk. "Eksistensi 'Urf Sebagai Sumber Pelembagaan Hukum Nasional." Al-Jamiah 54, no. 1 (2014): 1000168. https://doi. org/10.24042/adalah.v15i1.3383. 
Umam, Khotibul. "Legalisasi Fikih Ekonomi Perbankan: Sinkronisasi Peran Dewan Syariah Nasional dan Komite Perbankan Syariah.” Mimbar Hukum 24, no. 2 (Juni 2012): 360. 